\title{
O DIREITO ROMANO E AS ORIGENS DO TRABAL.HO AUTÔNOMO
}

\author{
Otávio Pinto e Silva \\ Professor Doutor do Departamento de Direito do \\ Trabalho da Faculdade de Direito da \\ Universidade de São Paulo.
}

Resumo:

O presente estudo analisa a regulamentação da prestação de serviços no Direito Romano, para apontar as origens remotas daquilo que hoje se classifica como o trabalho autônomo.

Abstract:

The present study analyses the regulamentation of labor relations in the Roman Law, in order to point out the remote origins of what is known today as autonomous work

Unitermos: Direito Romano; trabalho autônomo.

Keywords: Roman Law; autonomous work.

1. Introdução

Ensina José ('arlos Moreira Alves que a locação ("locatio conductio") era o contrato pelo qual alguém, mediante remuneração ("merces"), se obrigava a:

a. proporcionar a outrem o uso, ou o uso e o gozo, de uma coisa ("locatio conductio rei");

b. prestar um serviço a outrem ("locatio conductio operarum");

c. realizar uma obra para outrem ("locatio conductio operis").

Ou seja, existia somente um tipo de locação. mas com finalidades diversas, sendo que a "locatio conductio rei" é a mais antiga e dela derivaram as outras.

Observa Francis de Zulueta que essa classificação não era conhecida no Direito Romano, mas é uma modema sumarização dos casos concretos encontrados nos textos. ${ }^{2}$

1. ALVES, José Carlos Moreira. Direito romano. Rio de Janeiro: Forense, 1980, v. 2, p. 211.

2. ZULUETA, Francis de. The Institutes of Gaius (part II - commentary). Oxford: Clarendon Press, 1953. p. 171. 
A doutrina de Dircito do Trabalho costuma apontar esses institutos do Direito Romano como a origem remota da regulamentação do trabalho, que posteriormente seria dividido em trabalho aulônomo e trabalho subordinado.

Vejamos, então, como cram disciplinados os contratos de locação de serviços e de obra.

\section{I.ocatio Conductio Operis}

$\mathrm{Na}$ "locatio conductio operis", o "locator" entregava ao "conductor" uma ou mais coisas para que servissem de objeto do trabalho que este se obrigava a realizar para aquele.

Por exemplo, o "locator" entregava suas roupas ao "conductor". para que este as lavasse. Outro exemplo: objetivando a construção de uma casa, o "locator" fornecia o material de construção ao "conductor" para que este trabalhasse na obra.

Como se pode perceber, o objeto do contrato não era a atividade do empreiteiro, mas sim o material que o dono da obra entregava a ele para a realização da obra contratada.

Era imprescindivel que a coisa objeto do trabalho a ser realizado pelo "conductor" the fosse fornecida pelo "locator". uma vez que, segundo o ensinamento de Gaius, se o próprio empreiteiro fornecesse o material. não estaríamos diante de uma "locatio conductio operis" mas sim de uma compra e venda ("emptio venditio")."

O "conductor", que devia observar as normas técnicas necessárias para que sua obra atingisse o objetivo esperado, se obrigava não ao trabalho (abstração feita de seu resultado), mas sim ao resultado final da obra a realizar.

Sendo assim. excetuando-se apenas a hipótese de o contrato ter sido celebrado tendo em vista as qualidades pessoais do "conductor". em geral este não estava obrigado a realizar a obra pessoalmente. de modo que nem mesmo a sua morte extinguia a "locatio conductio operis"

3. GAIUS. Institutas, III, 147. Tradução de Alfredo di Pietro. La Plata: Ed. Libreria Jundica 1967.p. 239. 
A obra deveria ser efetuada dentro do prazo previsto no contrato ou, se nada tivesse sido convencionado a respeito, no espaço de tempo que normalmente seria necessário para concluí-la.

Havia responsabilidade do "conductor" relativamente às coisas que recebia do "locator" de tal modo que em algumas hipóteses respondia por dolo e culpa no perecimento delas.

Podia também responder por custódia, em especial nos casos de furtos de coisas que recebia do "localor" e que a este deviam ser restituidas (como por exemplo as roupas entregues ao tintureiro).

$\mathrm{O}$ "conductor" respondia também por danos decorrentes de imperícia profissional.

A responsabilidade cessava no momento em que o "locator" depois de examinar a obra, a aprovasse ("adprobutio operis").

O pagamento da "merces" em geral se realizava apenas no término da obra, salvo disposições em contrário estabelecidas pelas partes contratantes.

\section{Locatio Condutio Operarum}

$\mathrm{Na}$ "locatio conductio operarum" era o "locator" quem estava obrigado a prestar serviços ao "conductor"

Diferentemente da hipótese anterior, aqui o "locator" se obrigava exatamente à prestação de serviços, abstração feita de seu resultado final ("locare operas suas"). Um exemplo: pessoa contratada para trabalhar por um dia, fazendo tudo o que lhe fosse solicitado pelo contratante.

Nesse caso, a prestação das chamadas "operae" devia ser efeluada pessoalmente pelo "locator" extinguindo-se o contrato com a sua morte. Se era o beneficiário dos serviços quem morresse ("conductor"), suas obrigações se transmitiam aos herdeiros.

É necessário salientar que o "locator" estava obrigado a prestar ao "conductor" não qualquer espécie de trabalho, mas apenas aqucles serviços que costumeiramente eram atribuídos aos escravos (em geral, tarefas manuais).

Segundo José Carlos Moreira Alves, isso se explica pelo fato de que a "locatio conductio operarum" resultou da "locatio conductio rei": quando esta tinha por objeto um escravo, o "conductor" podia se utilizar dos serviços dele. 
Com a evolução do instituto, chegou-se a admitir que um homem livre pudesse dar em locação os seus serviços. Certo, então, que tais serviços seriam materiais, como os que os escravos comumente prestavam. ${ }^{4}$

Ressalve-se, por fim, que as chamadas artes liberais, como por exemplo a medicina, não eram objeto de "locatio conductio operarum", pois estavam fora do campo contratual.

4. Trabalho Humano entre atividade c resultado.

Essa análise dos institutos do direito romano costuma ser apontada como o fundamento para a classificação das modalidades de trabalho humano, levando em consideração a atividade e o resultado.

Edoardo Ghera, porém, assevera que a distinção entre atividade e resultado do trabalho, embora aparentemente clara, é na realidade ambígua, pois por um lado acentua a identidade de objeto devida pelo trabalhador nos dois tipos de contrato (a força de trabalho), mas de outro distingue a natureza e a causa do trabalho segundo os riscos existentes, trazendo alguma incerteza. ${ }^{5}$

Os riscos no desenvolvimento das atividades do trabalhador podem ser classificados em dois grupos:

a) os que incidem sobre o bem produzido; ou

b) os que resultam da falta ou impossibilidade de trabalho.

O primeiro tipo de risco é o incidente sobre a utilidade produzida com a prestação do trabalho ("commodum obligationis").

É um risco que depende das dificuldades técnicas e econômicas para a obtenção do resultado, estando portanto relacionado aos fatores da produtividade e da organização do trabalho.

São exemplos desse tipo de risco: os imprevistos técnicos surgidos com o material (que levem o trabalhador a gastar mais tempo do que pensava na realização da obra), ou ainda o aumento do preço da matéria prima (que reduza a margem de lucro do trabalhador), e até mesmo fatores naturais (como um raio) que destruam o produto pronto e estocado, antes que o seu destinatário possa dele dispor.

4. ALVES, José Carlos Moreira. op. cit. p. 218.

5. GHERA, Edoardo. Diritto del lavoro. Bari: Cacucci Ed.. 1985. p. 36. 
Trata-se portanto de um tipo de risco que está ligado às variantes econômicas do rendimento da energia de trabalho e por isso sujeito às incertezas de valores do resultado obtido.

Já o segundo tipo de risco é o decorrente da falta ou da impossibilidade de trabalho, em virtude de caso fortuito ou de força maior, ou de fatores que impedem a execução da prestação pelo trabalhador ("periculum obligationis").

São exemplos tanto as hipóteses que envolvem causas subjetivas (doença, gravidez, invalidez) quanto objetivas (interrupção da atividade produtiva por falta de energia, de matéria prima, ou ainda em virtude de fenômenos naturais como furacões, inundações etc.).

Para o Direito Romano, os riscos no desenvolvimento das atividades do trabalhador devem ser repartidos entre os contratantes de forma diferente, dependendo do tipo de contrato.

Sendo assim, na "Iocatio operis" o risco é integralmente do trabalhador, que se obriga a prestar a obra pronta ("opus perfectum"), qualquer que seja o custo suportado para obter o resultado.

Já na "locatio operarum" o risco do resultado é do emprecndedor, pois o trabalhador se obriga a prestar a sua energia limitando-se a suportar apenas o perigo da falta ou impossibilidade de trabalho.

Vale dizer, o segundo tipo de risco acima examinado ("periculum obligationis") é sempre suportado pelo trabalhador, enquanto o primeiro ("commodum obligationis") é dividido entre as partes, dependendo do tipo de contrato.

\section{Conclusão.}

Modernamente, o critério de subordinação ou dependência foi desenvolvido pela doutrina de Direito do Trabalho como um recurso sucessivo para buscar afastar as incertezas decorrentes da avaliação do risco do trabalho.

Dessa forma, gradualmente o contrato de trabalho subordinado foi se destacando do tronco original da "locutio conductio rei et operis". 6 ao passo que o 
trabalho autônomo manteve as ligações com as origens de sua regulamentação no Direito Romano.

São Paulo, julho de 2003.

6. Bibliografia.

ALVES, José Carlos Moreira. Direito Romano. Rio de Janeiro: Forense, 1980. v. 2. GAIUS. Institutas. III, 147. Tradução de Alfredo di Pietro. La Plata: Ed. Libreria Juridica, 1967.

GHERA, Edoardo. Diritto del lavoro. Bari: Cacucci Ed., 1985. p. 36

ZULUETA, Francis de. The Institutes of Gaius (part 11 commentary). Oxford: Clarendon Press, 1953. 